\title{
Many-sided performance testing of Finnsheep rams
}

\author{
M.-L. PUNTILA \\ Department of Animal Breeding, Agricultural Research Centre. \\ SF-31600 Jokioinen, Finland
}

\begin{abstract}
Central performance testing of young rams has been conducted in Finland since 1975 , in 1985-87 indoors as combined phenotype and 1/2-sib tests, which are the subject of this study.

There were 100 individual boxes available, of which ca. 90 were annually used for Finnsheep (F). The rams were fed on concentrate diet $(13.5 \% \mathrm{DCP})$ ad lib. + hay. The test period was from 60 to 150 days of age. Feed intake (FI) was recorded daily, live weights (LW) fortnightly. At the end, MLD-areas were ultrasonically scanned, fleeces weighed, some linear body measurements taken, and fleshiness and wool quality scored. A total of $276 \mathrm{~F}$ rams were tested. They were progeny of 85 sires ( $2-4$ half-brothers/sire).

The means for all rams (30 selected rams) were: birth type 3.19 (3.18), rearing type 2.93 (3.01), age at start 64.3 (63.7) days, 60-day LW 19.5 (19.5) kg, 150-day LW 45.1 (47.6) kg, ADG $284(312) \mathrm{g} / \mathrm{d}$, FI 1.28 (1.34) kg/d, FE 4.49 (4.29) kg/kg gain, MLD-area 8.83 (9.63) $\mathrm{cm}^{2}$.

There was considerable variation in the important traits (ADG, FI, FE, MLD-area), in spite of preselection.

The phenotypic correlations of ADG with 150-d.LW, FI, FI/ kg gain and MLD-area were $.61, .57,-.63$ and .37 , resp. $(\mathrm{P}<.001)$. Those of 150 -d.LW with the last three traits were $.59,-.15 \mathrm{NS}$ and 0.44 , resp. $(\mathrm{P}<.001)$. Selection for ADG, 150-d. LW, FI/kg gain and MLDarea in the performance test appeared to improve the value of offspring for meat production in $\mathrm{F}$.
\end{abstract}

Index words: Finnsheep, performance testing, ultrasonic, feed intake, feed efficiency, growth rate

\section{Introduction}

In a country like Finland, with very small flocks, within-flock selection cannot be intense, and comparison of animals across flocks is difficult. Varying pasture conditions further reduce the reliability of field testing.
Fewson (2) emphasized the importance of central performance tests in increasing the accuracy of genetic evaluation. Its value in selection for growth rate was confirmed in several studies $(25,17,16,20,26,12,23)$.

Selection for meat production in sheep suffers from lack of good measures for 
predicting the carcass composition from live animals. Hence, centralized sib-testing stations are used in selecting rams for carcass traits (15).

Ultrasonic measurements are not as common in sheep as in cattle and pigs, in predicting carcass traits, due to the poor precision of prediction $(11,3,19)$. Attempts to use them on lambs have been disappointing, because of the small variation in backfat thickness and muscle area or depth. However, some reports show the measurements to be of some value in predicting carcass composition $(13,1)$. Finnish results of testing rams with Scanogram (4) presume it to be useful under intensive feeding, but not under pasture conditions. It may also be more advantageous in meat type breeds. Scanning may be a good tool, if the emphasis in evaluation is on lamb cutlets (5). Despite the modest improvement in predicting the carcass lean proportion, Kempster (14) suggests ultrasound to be useful in selection programmes. Using the new real time scanner has also been shown to be justified in circumstances like at central testing stations (15). It is worth mentioning that ultrasonic measurements have been routinely used in performance testing of rams of various breeds in Denmark since $1977(6,7,8,9,10)$.

Station tests give the prerequisites for measuring individual feed consumption. There is clearly some interest to include the traits of feed efficiency also as one of the selection criteria $(8,21)$.

\section{Previous performance tests in Finland}

The first central performance tests were carried out in 1975-77 as combined phenotype and progeny test, including comparisons between rearing indoors and on pasture. The results showed the performance tests to be well applicable to evaluating sheep for carcass traits. During 1981-84 the tests were carried out on natural pasture. Low growth rates did not stimulate breeders to buy rams tested in this way, therefore the test in that form was discontinued.
The objectives of the current study were to analyze data recorded for growth rate (ADG), feed intake (FI) and ultrasonic measurements, to describe the influence of non-genetic factors and to estimate the phenotypic parameters of the most important traits.

\section{Material}

The performance test data spans three years from 1985 to 1987 . There were records from 274 lambs (67 sires, 206 dams). Average number of lamb records per sire was 3.1. The performance test station at Jokioinen has the capacity for 100 rams. In addition to Finnsheep some Texel and Rygja rams were tested, they are not included in this study. The performance test was a combined half-sib test. The object was to have four half-sibs per sire, although groups of two and three also existed. The rams came from recorded flocks throughout the country. The pre-selection was made by extension technicians. There were recommendations for feeding and weaning of lambs at the farm before the test period. The birth data was restricted to be from late February to early April. Hence there was quite a lot of age variation at the beginning of test. The test period was 90 days, from 60 to 150 days of age. The initial weights were adjusted to 60 days of age. The rams were kept in individual pens and fed on concentrate diet to appetite, roughage was under restriction. FI was recorded daily, growth rates fortnightly. At the end of test rams were ultrasonically measured behind the last rib. The scanning equipment used was a B-model linear real time Hitachi EUB 27 scanner. In the first and third year some linear body measurements were taken, too. Fleece and fur characteristics and structural soundness were evaluated. Growth, feed efficiency (FE) and meatiness indices were calculated separately for each ram, utilizing sib information. The best ranked animals were sold at auctions to farmers, few being used for artificial insemination. The rest were slaughtered immediately after the test. Dur- 
ing the first two years these carcasses were dissected for determining carcass composition.

\section{Methods}

Data were analyzed by the GLM procedure in SAS. The general statistical model included fixed effects due to year, rearing type $(1-5)$, age of dam (2-7 years or more) and birth flock, and the age of lambs at the beginning of test as a covariate. Only phenotypic correlations were possible to calculate. Pedigree indices were based on half sibs with the heritabilities for daily gain, feed efficiency and meatiness (ultrasonic muscle area) .4, .3 and .3 respectively. The average relationship in sire progeny groups was estimated according to Osborne (1957).

\section{Results and discussion}

Overall means and coefficients of variation for weights and daily gain (ADG) in different periods are given in Table 1 . The CV for age at start was about $8 \%$, the same over the years, the mean being 64 days. Starting weight is the most variable trait due to both genetic and environmental factors. The $\mathrm{CV}$ for weight at different periods were $8-14 \%$ in each year, while periodic gains varied markedly between years. The growth pattern was typical for each year. In the first year the rams gained most during 6 first weeks in the test and in the year 1987 the situation was reversed. In general, the ADG was at its maximum on the third fortnight period. Mean ADG from 60 to 150 days was similar during all tests, varying within year from 172 to $370 \mathrm{~g}$. The results were in agreement with the previous performance test data where the rams were fed on concentrates (25). By dividing the rams to three weight groups according to starting weight, the lightest group had significantly better ADG in the test than the heaviest group. Consequently the major part of the rams fully utilizes growth potential during the test period. The average FI varied from 0.7 to $1.4 \mathrm{~kg}$ $\mathrm{DM} / \mathrm{d}, \mathrm{FE}$ from 3.2 to $5.7 \mathrm{~kg} \mathrm{DM} / \mathrm{kg}$ gain. Figure 1 describes the increase of FI on the group of immediate start weight during successive growth periods.

The analyses of variance are given in Table 2. The (non-genetic) factors included in the model had a significant or almost significant

Table 1. Overall means $(\bar{x})$ and coefficients of variation for daily gain $(\mathrm{g} / \mathrm{d})$ recorded fortnightly from 60 to 150 days of age in different years.

\begin{tabular}{|c|c|c|c|c|c|c|}
\hline \multirow[b]{2}{*}{ Trait } & \multicolumn{2}{|c|}{1985} & \multicolumn{2}{|c|}{1986} & \multicolumn{2}{|c|}{1987} \\
\hline & $\overline{\mathrm{x}}$ & C.V. & $\overline{\mathrm{x}}$ & C.V. & $\overline{\mathrm{x}}$ & C.V. \\
\hline Age at start & 63.5 & 7.7 & 64.9 & 7.8 & 64.5 & 8.6 \\
\hline Initial weight & 19.1 & 16.9 & 20.4 & 18.6 & 22.2 & 13.2 \\
\hline Adjusted 60 day weight & 18.0 & 16.6 & 19.4 & 19.4 & 21.1 & 12.2 \\
\hline Weight at period & 23.4 & 13.9 & 24.1 & 14.9 & 25.9 & 12.4 \\
\hline II & 27.8 & 11.9 & 28.3 & 13.6 & 29.7 & 11.7 \\
\hline III & 32.0 & 10.4 & 32.8 & 11.8 & 34.3 & 10.5 \\
\hline IV & 35.9 & 9.8 & 37.3 & 10.4 & 38.5 & 9.5 \\
\hline V & 39.5 & 9.3 & 41.4 & 10.2 & 42.7 & 9.7 \\
\hline VI & 42.6 & 8.9 & 43.8 & 8.3 & 45.7 & 7.9 \\
\hline Final weight ( $150 \mathrm{~d})$ & 43.3 & 8.5 & 44.9 & 9.1 & 46.9 & 8.8 \\
\hline Gain at period & 315 & 24.6 & 258 & 46.4 & 260 & 28.7 \\
\hline II & 312 & 24.6 & 304 & 27.7 & 276 & 31.3 \\
\hline III & 301 & 31.4 & 322 & 24.9 & 326 & 28.3 \\
\hline IV & 277 & 32.5 & 320 & 28.0 & 305 & 27.4 \\
\hline V & 259 & 36.9 & 297 & 28.1 & 299 & 29.3 \\
\hline VI & 247 & 43.7 & 245 & 44.7 & 274 & 33.4 \\
\hline ADG & 281 & 11.9 & 284 & 12.5 & 286 & 11.4 \\
\hline
\end{tabular}




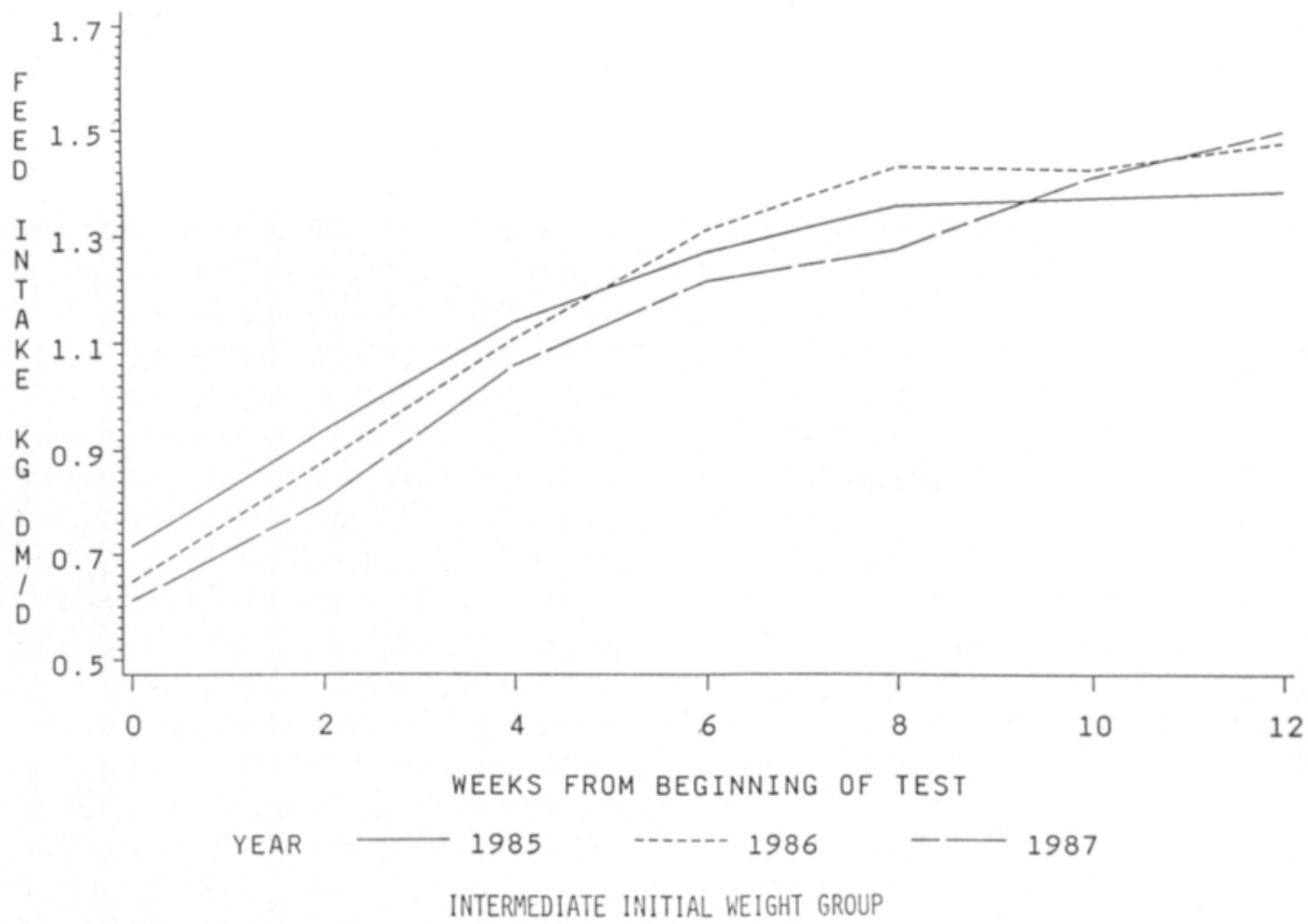

Fig. 1. Feed intake in different test years.

effect on the differences in the traits studied. The year of birth had a significant influence on all main traits except ADG. Age at beginning had a highly significant effect on the start weight as expected. The influence lasted until the final weight and overall ADG. Rearing type had a significant influence on the start weight as well as on 150 day weight. This is in agreement with the results of OLson et al. (17). The previous Finnish data indicated the rearing type to have an effect mainly on the weaning weight, not on the final weight (11). In this study the rams came from the litters averaging 3.2 (range $2-6$ ) and rearing type 2.9. Depending on the preselection the flocks had a fairly constant litter size.

Age of dam has usually been shown to have significant influence on ADG and body weight of lambs. Adjustment of the weaning weight to dam's age in the performance test has been considered necessary (17). In this study there was no significant effect of dam's age, prob- ably due to the fairly constant age of dams, $70 \%$ of them were $3-6$ years old.

The phenotypic correlations are presented in Table 3. The correlations between ADG, FI and final weight varied around .60.

As mentioned earlier, during the first two years the rest of the rams were slaughtered and dissected after the test period to evaluate the usefulness of ultrasonic muscle measurements in predicting carcass composition. The measurements were adjusted to the same live weight according to the recommendations of FORTIN et al. (3) even if there was some small variation in the live weight. Table 4 shows the results from the dissecting data (year 1986). The muscle area measurements seem to give slightly better association with carcass traits than muscle depth. The correlations between the real-time ultrasound live animal muscle measurements and dressing percentage as well conformation were around $0.50(\mathrm{p}<0.001)$ but between lean meat percentage and lean- 
Table 2. Analysis of variance for the effects of non-genetic factors on the most important traits in performance test.

\begin{tabular}{|c|c|c|c|c|c|c|c|}
\hline \multirow[b]{2}{*}{$\begin{array}{l}\text { Source of } \\
\text { variation }\end{array}$} & \multirow[b]{2}{*}{$\begin{array}{l}\text { Initial } \\
\text { weight }\end{array}$} & \multirow[b]{2}{*}{ ADG } & \multirow[b]{2}{*}{$\begin{array}{l}\text { Final } \\
\text { weight }\end{array}$} & \multirow[b]{2}{*}{$\begin{array}{l}\text { FI } \\
\text { intake }\end{array}$} & \multirow[b]{2}{*}{$\begin{array}{l}\text { FE } \\
\text { efficiency }\end{array}$} & \multicolumn{2}{|c|}{ Ultrasonic } \\
\hline & & & & & & $\begin{array}{l}\text { MLD- } \\
\text { area }\end{array}$ & $\begin{array}{l}\text { Muscle } \\
\text { depth }\end{array}$ \\
\hline Year & $109.21^{* * *}$ & $2786.97 \mathrm{~ns}$ & $73.88^{* * *}$ & $0.30^{* * *}$ & $2.16^{* * *}$ & $2.39^{*}$ & $13.58 * *$ \\
\hline Flock & $1228.46^{* * * *}$ & $94163.47^{* * *}$ & $1973.79^{* * *}$ & $1.11^{* * *}$ & $15.89^{* * * *}$ & $75.61^{* *}$ & $358.51^{* *}$ \\
\hline Rearing type & $225.34 * * *$ & $3264.21 \mathrm{~ns}$ & $160.82^{* *}$ & $0.04 \mathrm{~ns}$ & $0.50 \mathrm{~ns}$ & $3.08 \mathrm{~ns}$ & $20.48 \mathrm{~ns}$ \\
\hline Age of dam & $37.62 \mathrm{~ns}$ & $2293.08 \mathrm{~ns}$ & $16.12 \mathrm{~ns}$ & $0.02 \mathrm{~ns}$ & $0.20 \mathrm{~ns}$ & $1.38 \mathrm{~ns}$ & $13.11 \mathrm{~ns}$ \\
\hline $\begin{array}{l}\text { Age at } \\
\text { beginning }\end{array}$ & $304.73^{* * *}$ & $6452.73^{* *}$ & $72.25 * *$ & $0.00 \mathrm{~ns}$ & $1.35^{* *}$ & $0.03 \mathrm{~ns}$ & $2.47 \mathrm{~ns}$ \\
\hline $\mathbf{R}^{2}$ & 0.707 & 0.375 & 0.583 & 0.437 & 0.433 & 0.313 & 0.314 \\
\hline
\end{tabular}

ns $=\mathrm{P}>0.10, *=\mathrm{P}<0.05, * *=\mathrm{P}<0.01, * * *=\mathrm{P}<0.001$.

FI (kg DM/day)

$\mathrm{FE}$ (feed in $\mathrm{kg} \mathrm{DM} / \mathrm{kg}$ gain)

Table 3. Phenotypic correlations between initial weight (IW), final weight (FW), average daily gain (ADG), feed intake (FI), feed efficiency (FE), ultrasonic muscle area (MLD-area) and muscle depth (MLD depth).

\begin{tabular}{|c|c|c|c|c|c|c|c|}
\hline Traits & IW & FW & ADG & FI & FE & MLD-area & MLD-depth \\
\hline IW & & $.64 * * *$ & $-.13 \mathrm{~ns}$ & $.21 * * *$ & $.34 * * *$ & $.26 * * *$ & .05 \\
\hline FW & & & $.61^{* * * *}$ & $.59^{* * *}$ & $-.15^{* *}$ & $.44 * * *$ & $.32 * * *$ \\
\hline ADG & & & & $.57 * * *$ & $-.63^{* * *}$ & $.37 * * *$ & $.39 * * *$ \\
\hline FI & & & & & $.26 * * *$ & $.33 * * *$ & $.36 * * *$ \\
\hline FE & & & & & & $-.13^{*}$ &.$- .11^{*}$ \\
\hline MLD-area & & & & & & & $.55^{* * *}$ \\
\hline
\end{tabular}

ns $=\mathrm{p}>0.10, *=\mathrm{p}<0.05, * *=\mathrm{p}<0.01, * * *=\mathrm{p}<0.001$.

bone ratio not significant. The dissection data from the first year had the best predictors for carcass lean percentage when muscle depth was added to 150 day weight with the $\mathrm{R}^{2}$ value $0.27 * *$.

The numbers of rams tested and selected over years are given in Table 5. The averages and selection differentials have improved year by year. The difference in overall ADG during the three test years between tested and selected rams was $28 \mathrm{~g}$ corresponding to 10.14 standard deviation (s.d.) units, the same with final weight, namely $2.6 \mathrm{~kg}(0.22 \mathrm{~s}$.d. units). It is worth mentioning that the main selection criterion was ADG. Some individuals with good fur and wool characteristics were accepted though they did not rank in ADG among the 30 best ones. There were some rams each year which were also culled because of faults in conformation or some diseases.
Three different indices with measurements of ADG, FE and meatiness based on half sibs showed clear differences in ranking of rams. The aim was to give farmers information about growth rate, feed utilization and carcass quality in such a way that they could eas-

Table 4. Correlations between scanning measurements and carcass traits (adjusted to constant live weight, $\mathrm{n}=60$ ).

\begin{tabular}{lll}
\hline & \multicolumn{2}{l}{ Scanning measurement } \\
\cline { 2 - 3 } Carcass trait & $\begin{array}{l}\text { Muscle } \\
\text { area }\end{array}$ & $\begin{array}{l}\text { Muscle } \\
\text { depth }\end{array}$ \\
\hline Dressing percentage & $0.54 * * *$ & $0.41 * * *$ \\
Conformation $x)$ & $0.50^{* * *}$ & $0.26^{*}$ \\
Carcass muscle area & $0.55^{* * *}$ & $0.48^{* * *}$ \\
Total lean percentage & $0.15 \mathrm{~ns}$ & $0.03 \mathrm{~ns}$ \\
Lean-bone ratio & $0.22^{*}$ & $0.15 \mathrm{~ns}$ \\
\hline
\end{tabular}

x) meatiness points 
Table 5. Superiority (selection differentials) of selected rams to all tested rams.

\begin{tabular}{|c|c|c|c|c|c|c|c|c|c|}
\hline \multirow{3}{*}{ Trait } & \multicolumn{3}{|c|}{1985} & \multicolumn{3}{|c|}{1986} & \multicolumn{3}{|c|}{1987} \\
\hline & \multirow{2}{*}{$\begin{array}{c}\begin{array}{c}\text { Tested } \\
\mathbf{n}=90\end{array} \\
\overline{\mathbf{x}}\end{array}$} & \multicolumn{2}{|c|}{$\begin{array}{c}\text { Selected } \\
\mathrm{n}=30\end{array}$} & \multirow{2}{*}{$\begin{array}{c}\begin{array}{c}\text { Tested } \\
\mathrm{n}=94\end{array} \\
\overline{\mathrm{x}}\end{array}$} & \multicolumn{2}{|c|}{$\begin{array}{c}\text { Selected } \\
\mathrm{n}=33\end{array}$} & \multirow{2}{*}{$\begin{array}{c}\begin{array}{c}\text { Tested } \\
\mathrm{n}=90\end{array} \\
\overline{\mathrm{x}}\end{array}$} & \multicolumn{2}{|c|}{$\begin{array}{c}\text { Selected } \\
\mathrm{n}=27\end{array}$} \\
\hline & & sd & $\mathrm{S}$ & & sd & $\mathrm{S}$ & & sd & $\mathrm{S}$ \\
\hline Initial weight $(\mathrm{kg})$ & 19.1 & 3.22 & +0.2 & 20.4 & 3.81 & +0.6 & 22.2 & 2.94 & +0.8 \\
\hline Daily gain (g) & 281 & 33.61 & +22 & 284 & 35.64 & +34 & 286 & 32.69 & +28 \\
\hline Final weight $(\mathrm{kg})$ & 43.3 & 3.69 & +2.2 & 44.9 & 4.11 & +2.6 & 46.9 & 4.14 & +3.2 \\
\hline Feed intake & 1.13 & 0.12 & +0.07 & 1.12 & 0.10 & +0.04 & 1.08 & 0.10 & +0.08 \\
\hline Feed efficiency & 4.05 & 0.45 & -0.09 & 4.00 & 0.50 & -0.36 & 3.80 & 0.31 & -0.11 \\
\hline Muscle area $\left(\mathrm{cm}^{2}\right)$ & 8.7 & 0.95 & +0.5 & 8.7 & 1.12 & +0.4 & 9.1 & 1.04 & +0.5 \\
\hline Muscle depth (mm) & 24.4 & 2.07 & +0.8 & 23.3 & 2.26 & +0.9 & 23.7 & 2.36 & +1.4 \\
\hline
\end{tabular}

Feed intake in $\mathrm{kg} \mathrm{DM} / \mathrm{d}$

Feed efficiency in $\mathrm{kg} \mathrm{DM} / \mathrm{kg}$ gain

ily select the rams on the breeding value for the characteristics they wanted.

\section{Conclusions}

The results suggest that satisfactory progress has been made in ADG, FE and meatiness through the performance test. The averages and selection differential have improved each year. Superiority of selected rams over all tested ones was $28 \mathrm{~g}$ in ADG, $2.6 \mathrm{~kg}$ in 150 day weight, $-.18 \mathrm{kgDM} / \mathrm{kg}$ gain in $\mathrm{FE}$ and MLD-area $.56 \mathrm{~cm}^{2}$ in meatiness.

In Finland where the test capacity is restricted, the importance of central performance testing depends on the following factors:

- preselection of rams, i.e. how well the ped- igree information can be used in selecting potential ramlambs

- how reliable are the selection methods in ranking the rams

- how wide and systematic is the utilization of the best rams for breeding

At present the efficiency of performance testing is incomplete in a way that there is no progeny testing to monitor the validity of the performance test. Similar findings on inefficiency have been reported by THIELE-WITTIG (24), Shelton $(20,21)$ and Jensen \& Hansen (7). There is also too much emphasis on conformation by the sheep breeders. In the future the central performance test should be therefore combined with progeny testing. The economic values in the selection index will be considered. Also the rationalisation of the FI recording should be investigated to decrease the test costs.

\section{References}

1. Bass, J.J., Woods, E.G. \& Paulsen, W.D., 1982. A comparison of three ultrasonic machines (Danscan, AIDD (NZ) and Body Composition Meter) and subjective fat and conformation scores for predicting chemical composition of live sheep. J. Agric. Sci, Cambridge 99: 529-532.

2. Fewson, D., 1970. Zuchtplanung für die Reinzucht beim Schaf. Züchtungskunde 42, 6: 424-435.

3. Fortin, A. \& Shrestha, J.N.B., 1986. In vivo esti-

mation of carcass meat by ultrasound in ram lambs slaughtered at an average live weight of $37 \mathrm{~kg}$. Anim. Prod. 43: 469-475.

4. Hellman, T., Ojala, M. \& Varo, M., 1976. The use of ultrasonics in phenotype testing of rams. J. Sci. Agric. Soc. Finl. 48: 395-406.

5. -1980 . Individtest av bagglamm i Finland. NJF seminar om sauavl og saukontroll. Gøl 1980: $127-129$. 
6. JenSEN, N.E., 1980. Resultater fra scanning og dissection. NJF seminar om saueavl og saukontroll. Gøl 1980: 122-126.

7. - \& Hansen, K., 1982. Performance tests of ram lambs 1983. 538. Beretn. Statens Husdyrbr.fors: 31 pp.

8. - 1983. Individprøver med lam 1983. 557. Beretn. Statens Husdyrbr.fors.

9. - 1985. Performance tests of ram lambs 1985. 598. Beretn. Statens Husdyrbr.fors: $47 \mathrm{pp}$.

10. -1987 . Performance tests of ram lambs 1987. 632 . Beretn. Statens Husdyrbr.fors: 38 pp.

11. Kаталама̃кı, U., 1979. Yksilöarvostelun mahdollisuudet suomenlampaan lihantuotantokyvyn jalostamisessa (Possibilities of performance test in breeding for meat production in Finnsheep). Kotieläinjalostuksen Tiedote No. 34, 83 pp.

12. Kempster, A.J., Arnall, D., Aluiston, J.C. and BARKER, J.D., 1982. An evaluation of two ultrasonic machines (Scanogram and Danscanner) for predicting the body composition of live sheep. Anim. Prod. 34: 249-255.

13. -, Cuthrertson, A., Jones, D.W., \& Owen, M.G., 1981. Prediction of body composition of live cattle using two ultrasonic machines of differing complexity: a report of four separate trials. J. Agric. Sci., Cambridge 96: 301-307.

14. - 1983. Carcass quality and its measurements in sheep. In Sheep Production (ed. W. Haresign); pp. 59-74. Butterworths, London.

15. Kranth, R. \& Nitter, G., 1986. Prediction of carcass composition with ultrasonic measurements on live lambs. 37th Ann. Meet. Eur. Ass. Anim. Prod., Budapest, Hungary.

16. Mroue, B., 1979. Păssien yksilökokeen kăyttőarvo kasvuominaisuuksien arvostelussa. Kotieläinjalostuksen tiedote No. 30. 150 p.

17. Olson, L.W., Dickerson, G.E. \& Climp, H.R. 1976 Selection criteria for intensive market lamb production: Growth traits. J. Anim. Sci. 43: 78-89.

18. Osborne, R., 1957. The using of sire and dam family averages in increasing the efficiency of selective breeding under a hierarchical mating system. Heredity 11: 93-116.

19. Puntila, M-L., 1986. Experiences of using ultrasound scanner for evaluation of body composition in young Finnsheep rams. 37th Ann. Meet. EAAP, Budapest, Hungary.

20. Shelton, M., 1979. Estimation of genetic change in performance testing program for sheep. J. Anim. Sci. 48: 26-31,

21. -1984 . Recend trends in sheep breeding and improvment programs. The contribution of central performance test programs. Proc. 2nd World Congr. Sheep \& Beet Cattle Breed. Pretoria: 275-281.

22. - \& Lewis, R. Ram performance testing (in Texas). - A review and evaluation. Techn. Rep. no 86-3, Texas A \& M Univ. Agric. Res. and Ext. Center, 1986, 26 pp.

23. Shrestha, J.N.B., Vesely, J.A. \& Chesnais, J.P., 1985. Genetic and phenotypic parameters for daily gain and body weights in Suffolk lambs. Can. J. Anim. Sci. 65: 575-583.

24. Thiele-Wittio, H., 1976. Stationäre Fleischleistungsprüfung beim Scah-Stand und Entwicklungsperspektiven. Der Tierzüchter 28, 2: 46-48.

25. VARO, M., 1968. Lampaiden kasvatuskokeiden tuloksia. Ann. Agric. Fenn. 7: 33-45.

26. Ósterberg, S., 1980. Individtest av bagglamm i Finland. NJF Seminar om Saueavl og sauekontroll. Gøl. 1980: $71-78$. 